\title{
Impact of Tillage and Irrigation Management on Bell Pepper (Capsicum annuum L.) Grown in Organic and Conventional Production Systems
}

\author{
Zheng Wang ${ }^{1}$ \\ Department of Horticulture and Crop Science, The Ohio State University \\ OARDC, 1680 Madison Avenue, Wooster, OH 44691
}

Mark Williams and Krista Jacobsen

Department of Horticulture, University of Kentucky, 1100 South Limestone

Street, Lexington, KY 405463

\section{Timothy Coolong \\ Department of Horticulture, The University of Georgia, Tifton Campus, 2360 Rainwater Road, Tifton, GA 31793}

Additional index words. conservation tillage, drought, automated irrigation, plastic mulch, zone tillage

\begin{abstract}
Trials were conducted in 2011 and 2012 with 'Aristotle' bell pepper (Capsicum annuиm L.) grown under different tillage methods and irrigation regimes in organically and conventionally managed production systems. Treatments consisted of strip tillage or plastic mulch in well-watered or water-restricted irrigation regimes. Within organic and conventional production systems, the study was arranged as a split-plot randomized block design with strip tillage or plastic mulch as the main plot and irrigation regime as subplot. Leaf water potential $\left(\Psi_{L}\right)$, soil penetration resistance (compaction), volumetric water content (VWC), soil temperature, and pepper yield were measured. Soil VWC was greater in strip-tillage plots compared with plastic mulch plots under both well-watered and water-restricted conditions for plots in the organic system in 2011 and conventional system in 2012. In addition, soil VWC was numerically lower, if not always statistically different, in water-restricted plots compared with well-watered plots. The trend of soil temperatures within each production system were similar in 2011 and 2012, with plastic mulch plots having slightly higher soil temperatures than strip tillage, despite using white-on-black plastic mulch. Midday $\Psi_{L}$ was affected by water regime, with wellwatered plants having a significantly lower $\Psi_{L}$ than water-restricted plants; however, there were no effects of irrigation on predawn $\Psi_{L}$. Tillage method and sampling location (between row and within row) significantly interacted to affect soil penetration resistance in 2011 and 2012. There was a significant interaction of tillage by irrigation regime on yield within conventional systems in both years, but not in organically managed plots. In 2011, yield data also indicated that the date at which $50 \%$ of marketable fruit were harvested (yield_mid) were later for strip-tillage-grown plants than plastic mulchtreated plants within conventional and organic production systems, respectively.
\end{abstract}

High-value vegetable crops such as bell pepper are typically grown in the United States using plastic mulch with drip irrigation (Locascio, 2005). Plastic mulch can enhance productivity by warming soils, reducing inrow weed competition, and reducing evaporation (Lamont, 2005). However, plastic

Received for publication 10 Aug. 2015. Accepted for publication 17 Sept. 2015.

We would like to acknowledge the Center for Crop Diversification at the University of Kentucky for providing funding for this work.

This manuscript formed a portion of a dissertation submitted by $\mathrm{Z}$. Wang in fulfilling a $\mathrm{PhD}$ degree requirement at the University of Kentucky.

${ }^{1}$ Corresponding author. E-mail: wang.2735@osu. edu. mulch can also have negative environmental impacts. In addition to disposal issues (Hemphill, 1993), plastic mulch requires intensive tillage, which may reduce soil carbon sequestration, microbial biomass, and aggregation of soil particles, resulting in the destruction of soil structure (Roper et al., 2010). Runoff and erosion can also be severe in plastic mulch systems after heavy rains (Lamont, 1993). Due to some of the negative attributes of plastic mulch, there has been increased interest in conservation tillage systems for vegetable production (Luna et al., 2012).

Routinely used in the production of agronomic crops, conservation tillage includes a wide range of practices that rely on minimizing soil disturbance. Compared with traditional tillage methods, conservation tillage has been shown to improve soil structure and quality, reduce nutrient leaching, retain soil moisture, overcome soil compaction, and enhance soil microbial activity (Al-Kaisi and Licht, 2004; Buyer et al., 2010; Licht and Al-Kaisi, 2005; Mochizuki et al., 2007, 2008). Long-term trials have reported enhanced diversity of soil microbes in farming systems integrating organic production with conservation tillage. However, increased weed pressure, particularly in organic systems, low spring soil temperatures, and poor seedbed conditions are obstacles for widespread use of conservation tillage in some vegetables (Walters, 2011).

Strip tillage is a form of conservation tillage that tills narrow rows in fields, leaving the between-row areas undisturbed. By restricting tillage to a portion of the total field area, strip tillage may provide the benefits of both traditional and conservation tillage. Strip tillage, when used in vegetable crops, often relies on fall-planted cover crops in lieu of crop residues to provide soil coverage and prevent erosion during winter (Carrera et al., 2007). These cover crops, when killed the following spring, provide organic matter, which may lead to enhanced soil moisture content in the intercropped areas, potentially affecting yield (Haramoto and Brainard, 2012; Wagner-Riddle et al., 1997; Wilhoit et al., 1990). Haramoto and Brainard (2012) reported a consistent increase in soil moisture levels in striptillage-grown cabbage (Brassica oleracea L.) compared with conventional tillage, some of which was attributed to increased available water in the strip-tillage-grown plants. In addition to enhancing soil moisture status, between-row mulches may provide weed suppression (Kong et al., 2009) and act as a source of organic matter and fertility, particularly in organic systems (Hoyt, 1992).

On-farm observations by the authors have suggested that strip tillage has been increasingly adopted for the production of sweet corn (Zea mays L.) and pumpkin (Cucurbita реро L.). Indeed, previous studies have reported comparable yields between strip tillage and conventional tillage in both sweet corn (Luna and Staben, 2002) and pumpkin (Rapp et al., 2004). Both crops are well suited for strip-tillage production. Sweet corn has a wide range of herbicides for weed control and a vigorous upright growth habit (Coolong et al., 2011a). Pumpkins are generally planted in late spring or early summer, after soils have warmed, and also have an aggressive growth habit, which can help shade weeds. However, it has been reported that several vegetable crops have performed poorly in strip-tillage systems. For example, organicmanaged broccoli (B. oleracea) grown with strip tillage, yielded $\approx 15 \%$ less compared with that grown with traditional tillage (Luna, 2003). Organic strip-tillage production can be particularly challenging. Traditionally, conservation tillage systems rely heavily on chemical herbicides due to an inability to cultivate nondisturbed areas (Morrison, 2002). Because cultivation is heavily used for weed management in 
organic systems, organic growers must often modify their production practices to incorporate strip tillage into their farming system. Typically this requires using cover crop residues as a mulch to prevent weed emergence. Managing weeds in the tillage zone can also be an issue due to a lack of mulch residue and the need for dedicated in-row cultivation.

There is a growing interest in strip tillage in vegetable crops due to the potential for these systems to improve soil quality. Previous research suggests that the success of strip tillage depends on the type of crop grown, production system, soil type, and soil moisture status. In addition, it has been shown that conservation tillage may enhance growth under water-restricted conditions due to the ability of crop residues to hold water in the soil (Haramoto and Brainard, 2012). An increase in organic matter that often accompanies strip tillage may also assist water in upward movement into the root zone through capillary action. However, variability in soil textures even within a small area can affect water movement (Jury and Horton, 2004), resulting in potential in-field variability within strip-tillage systems. Strip tillage has rarely been compared with a plastic mulch production system, with most trials instead comparing strip tillage to bare-ground production. Under well-watered conditions, plastic mulch may be more productive than strip tillage. However, under water-restricted conditions strip tillage and plastic mulch yields may be comparable due to the increased organic matter in a strip-tillage based system. This increased organic matter may increase soil water-holding capacity enough to offset the reduction in evaporation of soil moisture that may occur in the plastic-much system. To test these hypotheses bell pepper was grown under strip tillage or plastic mulch under two different irrigation regimes (well watered and water restricted) within conventional and organic production systems. It was not an objective of this study to compare organic and conventional production systems, but instead to evaluate the interaction of tillage and irrigation within each.

\section{Materials and Methods}

Plot establishment. This trial was conducted at the University of Kentucky Horticulture Research Farm in Lexington, KY (lat. $38^{\circ} 3^{\prime} \mathrm{N}$, long. $84^{\circ} 30^{\prime} \mathrm{W}$ ), in 2011 and 2012. The experimental fields (organic and conventional) were located in close proximity to one another. Cropping histories of fields were similar (mixed vegetable production using plastic mulch). Land for organic production in 2011 and 2012 was in years two and three, respectively, of being transitioned to organically certified crop land according to U.S. Department of Agriculture (USDA) standards (USDA, 2014). Experimental fields were rotated such that the same piece of land was not used in both trial years. Soils were a Maury silt loam series ( $0 \%$ to $2 \%$ slope); a fine, mixed, mesic Typic Alfisol.
Treated (Thiram film coat; Thiram $50 \mathrm{WP}$, $2.5 \mathrm{~g} \cdot \mathrm{kg}^{-1}$ seed; Bayer Crop Science, Research Triangle Park, NC) and untreated pepper 'Aristotle' (Seminis, St. Louis, MO) seeds were placed into 98-cell greenhouse trays filled with soilless media (Pro-Mix BX; Premier Tech, Riviere-du-loup, Canada) or a certified organic potting mix (Premium Organic Potting Soil, McEnroe Organic Farm, Millerton, NY), respectively, on 19 Apr. 2011 and 4 Apr. 2012. Seedlings were greenhouse-grown with set points of $26 / 20^{\circ} \mathrm{C}$ day/night. On 13 June 2011 and 30 May 2012, seedlings were transplanted into 7- to $8-\mathrm{cm}$ tall-raised beds covered with $1-\mathrm{mm}$ embossed white-on-black plastic mulch or bare soil (strip-tillage plots). Both treatments received a single line of drip irrigation tubing (30.5 $\mathrm{cm}$ emitter spacing, $1.0 \mathrm{~L} \cdot \mathrm{h}^{-1}$, AquaTraxx; Toro, El Cajon, CA) placed in the center of each plastic mulch bed or tilled strip. Transplants were placed in double rows on each plastic mulch bed with $\approx 35$ to $40 \mathrm{~cm}$ spacing between the double rows on a bed and $38-\mathrm{cm}$ within-row spacing. Plastic mulch beds were spaced $1.83 \mathrm{~m}$ center to center in plots. Transplants were placed in single rows on each strip-tillage bed with $30-\mathrm{cm}$ withinrow spacing. Strip-tillage beds were spaced $1.07 \mathrm{~m}$ center to center in plots. Target plant populations were 30,600 and 28,700 plants/ha in the strip tillage and plastic mulch systems, respectively. Plots were arranged in a split-plot randomized block design within organic or conventional production systems. Tillage was assigned as the main plot, and irrigation regime assigned as the subplot with three replications of each combination within organically and conventionally managed fields.

Plot arrangement differed slightly in 2011 and 2012. In 2011, within each main plot (tillage treatment), each subplot consisted of eight rows total, three of rows each were randomly assigned either water-restricted or well-watered treatments with borders on the outside rows. In 2012, due to space limitations, there were four rows total within each subplot, of which the middle two rows were randomly assigned as the irrigation treatment (well watered or water restricted), with the outside two rows serving as borders. Rows were 26 and $15 \mathrm{~m}$ in length in 2011 and 2012, respectively, although the harvested lengths of each row were 15 and $12 \mathrm{~m}$ in 2011 and 2012, respectively.

Winter rye (Secale cereale L.) (Southern States Cooperative, Lexington, KY) and hairy vetch (Vicia villosa) (Southern States) were seeded using a grain drill at rates of 56 and $22 \mathrm{~kg} \cdot \mathrm{ha}^{-1}$, respectively, in the last week of September in both study years in organic plots. Conventionally managed plots were seeded with wheat (Triticum sp.) in 2011 and winter rye in 2012 on the same day. Hairy vetch was not used in conventional plots to emulate a typical conventional system in which a winter grain would typically be used alone for a cover crop. For strip-tillage plots in the organic production system, cover crops were roller-crimped (Buffalo Stalk Chopper;
Bison Industries Inc., Norfolk, NE) twice in early and mid-May in both years. For striptillage plots in the conventional system, winter cover crops were killed with an application of glyphosate (784 g.ha ${ }^{-1}$, Roundup WeatherMax; Monsanto, St. Louis, MO). Strip-tillage plots were prepared by making two passes with a strip tiller (Model 6000; Hiniker, Mankato, MN). In plastic mulch plots, cover crops were mowed with a flail mower. Organic fields were prepared using a rotary spader (Model 35; Imants BV, Reusel, the Netherlands), whereas conventional fields were prepared using a moldboard plow. The two methods of primary tillage reflect different practices of organic and conventional growers in the region. During Summer 2011, organic and conventional plots to be used in 2012 were not tilled and were seeded with a sudex [Sorghum bicolor (L.) Moench $x$ Sorghum sudanense (P.) Staph.] cover crop using a grain drill at a rate of $34 \mathrm{~kg} \cdot \mathrm{ha}^{-1}$. The cover crop was mowed in mid-August and plots seeded in the fall with a winter ryehairy vetch mix for organic plots and winter rye for conventional plots as described previously. This was done to simulate a representative second year in a conservation tillage environment for the 2012 trial year. Fertility requirements for organic plots were determined by the contribution of the previous winter rye and hairy vetch cover crop using the Oregon State University cover crop calculator (Oregon State University, 2011) and soil test recommendations. The contributions of cover crop in organic plots were 78 and $84 \mathrm{~kg} \cdot \mathrm{ha}^{-1} \mathrm{~N}$ in 2011 and 2012, respectively. Additional fertilizer was applied in organic plots at rates of 90 and $84 \mathrm{~kg} \cdot \mathrm{ha}^{-1} \mathrm{~N}$ (10N-0.9P-6.6K; Nature Safe, Cold Spring, KY) in 2011 and 2012, respectively, under plastic mulch or in strip-tillage plots before planting. Therefore, this resulted in a total $\mathrm{N}$ input of $168 \mathrm{~kg} \cdot \mathrm{ha}^{-1}$ in both years. In conventional plots, preplant fertilizer was applied at $85 \mathrm{~kg} \cdot \mathrm{ha}^{-1} \mathrm{~N}(19 \mathrm{~N}-8.3 \mathrm{P}-15.8 \mathrm{~K}$; Southern States) directly under plastic mulch or in strip-tillage zones in 2011 and 2012. In 2011 and 2012, conventional plants received an additional $85 \mathrm{~kg} \cdot \mathrm{ha}^{-1} \mathrm{~N}(15.5 \mathrm{~N}-0 \mathrm{P}-0 \mathrm{~K}$, calcium nitrate; Southern States) in weekly applications of $17 \mathrm{~kg} \cdot \mathrm{ha}^{-1} \mathrm{~N}$, beginning 2 weeks after planting resulting in a total $\mathrm{N}$ input of $170 \mathrm{~kg} \cdot \mathrm{ha}^{-1}$ in both years. Weeds were controlled in organic plots with hand cultivation; while s-metolachlor $\left(917 \mathrm{~g} \cdot \mathrm{ha}^{-1}\right.$, Dual II Magnum; Syngenta, Greensboro, NC) was applied after planting between rows of conventional plots (strip tillage and plastic mulch). Fungicides and insecticides were applied weekly to conventional plots according to commercial recommendations for fresh-market peppers grown in Kentucky (Coolong et al., 2011a). However, immediately before the final harvest in 2011, some fall armyworm (Spodoptera frugiperda) damage was observed in conventionally managed plots, despite routine insecticide applications. Plots were scouted for insects and diseases weekly. Based on a lack of significant disease or insects detected in organic 
fields during scouting, it was not necessary to apply fungicides or insecticides to these fields.

Irrigation installation. All plots were watered uniformly for 3 weeks after planting in 2011 and 2 weeks after planting in 2012 to ensure an even plant stand. After establishment, irrigation regimes were implemented using an automated irrigation system (Coolong et al., 2013). In brief, irrigation timers (SVC; Hunter Industries, San Marcos, CA) were programmed to irrigate plots for 60 min every $2 \mathrm{~h}$ daily, from 7:00 AM to 9:00 PM (up to $8 \mathrm{~h}$ total daily). Solid-state electrical resistance sensors embedded in a granular matrix (Watermark $^{\text {TM }}$; Irrometer, Riverside, CA) were used to monitor soil water tension for the automated irrigation controllers. Each wellwatered or water-restricted plot was connected to a unique controller. Sensors were placed equidistant from two plants within a row at a depth of $15 \mathrm{~cm}$ beneath the surface of each plot (two per plot) and attached to a control module (Battery WEM; Irrometer). Sensors were about midway between drip emitters on the drip tape when placed; however, it should be noted that as temperatures changed during the growing season, the drip tape expanded and contracted making the distance between sensor and drip emitter variable. Each control module was wired to the timer/controller in lieu of a rain gauge to prevent irrigation when soil moisture content was above a predetermined soil water content threshold. Irrigation thresholds were set at $23 \% \mathrm{VWC}(-61 \mathrm{kPa})$ for well-watered treatments and $19 \%$ VWC $(-101 \mathrm{kPa})$ for waterrestricted treatments based on previously conducted research at the site using poblano pepper (C. annuum) and tomato (Solanum lycopersicum L.) (Coolong et al., 2011b, 2012). The values chosen reflected reasonable soil moisture levels for an irrigated crop that would be considered well watered and water restricted. The relationship of soil VWC to soil moisture tension for the site was determined using soil moisture release curves for the soils at the site (Nambuthiri and Coolong, unpublished data).

Soil VWC, temperature, and penetration resistance. Two soil moisture probes (EC-5 and 5-TM; Decagon Devices, Pullman, WA) were placed in each replication at depths of 15 and $25 \mathrm{~cm}$ below the soil surface in striptillage plots and the raised bed surface in plastic mulch plots. Probes were placed in a similar manner to the previously described Watermark $^{\mathrm{TM}}$ probes, which controlled irrigation. Probes were placed into intact soil, achieved by digging access holes adjacent to the plant bed and inserting probes in a parallel orientation with the soil surface. Probes were connected to data loggers (EM 50; Decagon Devices). In brief, each data logger was connected with five probes, of which two EC-5 and one 5-TM probes were used to measure soil VWC (three replications per treatment) and soil temperature (5-TM only) hourly at a $15 \mathrm{~cm}$ depth. The $15 \mathrm{~cm}$ depth was chosen because measuring soil VWC at this depth has been shown to be more reflective of irrigation treatments (Coolong et al., 2012; Jury and Horton, 2004).

Midseason penetration resistance was measured $\approx 8$ weeks after transplanting (8 Aug. 2011 and 25 July 2012) using a soil compaction meter (SC900; Spectrum Technologies, Plainfield, IL). For each treatment combination/replication, penetration resistance was measured within row and between rows. Within-row sampling locations were equidistant between plants and arranged across the plant bed perpendicular to planted rows. There were $\approx 5 \mathrm{~cm}$ between adjacent sampling locations and five locations in each row. Between-row sampling locations were adjacent to within-row locations starting from the center of the area between two treatment rows, with three between-row sample locations located $\approx 5-10 \mathrm{~cm}$ apart between each row. At each sampling location, penetration resistance was recorded every $5 \mathrm{~cm}$ at depths $5-30 \mathrm{~cm}$ below the soil surface. Soil VWC ranged from $21 \%$ to $25 \%$ when midseason soil penetration resistance was measured.

Plant water status. Predawn and midday $\Psi_{\mathrm{L}}$ was measured during growth on 18,22 , and 29 July; 6 and 19 Aug.; and 3 Sept. in 2011 and on 28 June; 18 July; and 1, 16, and 24 Aug. in 2012 using a pressure chamber (model 615; PMS Instrument Company, Albany, OR). Plant $\Psi_{\mathrm{L}}$ was determined by the method of Scholander et al. (1965). One recently matured, fully expanded leaf from each of three plants in each treatment/replication was selected to determine predawn and midday $\psi_{\mathrm{L}}$. Predawn measurements were performed from 5:30-6:30 AM and midday measurements conducted at 1:30-2:30 PM.

Harvest. Harvests were conducted on 10 and 23 Aug.; 13 Sept. 2011 and 26 July; 22 Aug.; 5 and 17 Sept.; 4 Oct. 2012, respectively. Harvested fruit were counted, weighed, and graded based on USDA fresh-market sweet pepper grade standards (USDA, 2005). Grades were categorized into U.S. Fancy, U.S. No. 1, U.S. No. 2, and cull fruit based on their shape, size, and color. Yields (weight and number of fruit) were obtained by summing up the weights and number of marketable and calculated based on length of harvested rows.

Statistical analysis. Data obtained from 2011 and 2012 were analyzed separately. For each year, analysis of variance of tillage treatment, irrigation regime, and their interactions were conducted within organic and conventional systems using SAS statistical software (version 9.3; SAS Institute, Cary, NC). Mean separations were analyzed using Fisher's least significance difference test $(P \leq 0.05)$. Soil VWC and temperature were analyzed from 30 June to 13 Sept. 2011 and from 16 June to 1 Sept. 2012 to have the same duration of time for analysis in each year, although the last harvest in 2012 was on 4 Oct. Yields were analyzed based on yield per 1000 plants to normalize the differences between plant populations in the two tillage systems. In addition, the variable yield_mid was created. This variable referred to the days after transplant at which $50 \%$ of the marketable fruit were harvested. In SAS, yield_mid was calculated by multiplying each harvest date with the corresponded fruit yield, summing up the product and then dividing by marketable yield.

\section{Results}

Soil moisture at a $15 \mathrm{~cm}$ depth. In 2011, no interactive effects were found within the conventional production system. Soil VWC in the well-watered treatment was greater than the water-restricted treatment for strip tillage and plastic mulch in the conventional system $(P \leq 0.05)$ (Table 1$)$. There was a significant interaction for tillage and irrigation regime for soil VWC within the organic production system. Average soil VWC for plastic mulch and strip-tillage treatments were 19.7 and $25.6 \mathrm{~cm}^{3} \cdot \mathrm{cm}^{-3}$, respectively, for plots exposed to the wellwatered irrigation regime. Average soil VWC was also significantly greater in the strip-tillage plots compared with plastic mulch under water-restricted conditions $\left(22.3\right.$ vs. $\left.18.8 \mathrm{~cm}^{3} \cdot \mathrm{cm}^{-3}\right)$ in the organic system (Table 1).

In 2012 , there was an interaction between tillage method and irrigation regime for soil VWC within the conventional production system (Table 1). Strip-tillage plots had a greater soil VWC than plastic mulch for both well-watered and water-restricted irrigation regimes; however, the magnitude of difference in soil VWC between the two tillage types differed. In the organic production system plastic mulch plots that were well watered had the greatest soil VWC, though this was not significantly different from strip-tilled plots under the well-watered irrigation regime. The total rainfall for the period analyzed in 2011 and 2012 were 28.3 and $18.6 \mathrm{~cm}$, respectively (Kentucky Mesonet, 2014).

Soil temperatures at $15 \mathrm{~cm}$. In 2011, the average daily soil temperatures within the conventional system were 26.3 and $25.0{ }^{\circ} \mathrm{C}$ for plastic mulch and strip-tilled plots, respectively (Fig. 1A). The average soil temperatures in the organic system were 25.9 and $23.5^{\circ} \mathrm{C}$ for plastic mulch and strip-tillage plots, respectively. The average air temperature during this period was $24.2^{\circ} \mathrm{C}$ (Kentucky Mesonet, 2014). In 2012, the average daily soil temperatures were 26.9 and $25.7^{\circ} \mathrm{C}$ for plastic mulch and strip-tilled plots, respectively, in the conventional system and 26.9 and $24.7^{\circ} \mathrm{C}$ for plastic mulch and strip-tilled plots, respectively, in the organic system (Fig. 1). The average air temperature during this time period was $25.2{ }^{\circ} \mathrm{C}$ (Kentucky Mesonet, 2014). There was no impact of irrigation on soil temperature regardless of tillage or production system in either study year (data not shown).

Leaf water potential. Neither production system or tillage regime had an effect on $\Psi_{L}$. However, midday $\Psi_{\mathrm{L}}$ was significantly greater in water-restricted plants than in 
well-watered plants in both study years (Fig. 2). Predawn $\Psi_{\mathrm{L}}$ was significantly less than midday $\Psi_{\mathrm{L}}$ at every sampling time in the trial. Because $\Psi_{\mathrm{L}}$ was only affected by irrigation regime during midday sampling and not the predawn sampling period, there was a significant interaction between sampling time and irrigation regime for $\Psi_{\mathrm{L}}$.

Midseason soil penetration resistance. Tillage method and sampling location significantly interacted to affect soil penetration resistance in 2011 and 2012 (Fig. 3). Trends were similar in both organic and conventional systems. Specifically, in both study years, within-row penetration resistance was greater for soils in strip-tillage-managed plots, with the exception of readings observed at the $30 \mathrm{~cm}$ depth in 2012, where there were no differences between the tillage regimes. However, when measured between rows, soil penetration resistance was less in strip-tillage plots at depths of 15 and $20 \mathrm{~cm}$ than in plastic mulch plots resulting in a significant interaction $(P \leq 0.05)$. Soil penetration resistance between rows did not differ between the two tillage regimes at other depths.

Yield. In 2011, there was a significant interaction of tillage and irrigation regime for marketable yield and number of fruit within the conventional production system. Under well-watered conditions, marketable yield and number of fruit were significantly greater for plants grown under plastic mulch compared with strip tillage ( $P \leq 0.05$, Table 2$)$. In addition, for plants grown within the organic system under well-watered conditions, the number of fruit produced by striptillage-grown plants was greater than plastic mulch-grown plants $(P \leq 0.05)$. There were significant tillage effects $(P \leq 0.05)$ for average fruit weight for plants produced under both production systems. The results indicated that average fruit weights for plastic mulch-grown plants under well-watered conditions were greater than in strip-tillagemanaged plants grown under the same irrigation regime. For yield_mid (days after transplant at which $50 \%$ of marketable yield was harvested), there were significant tillage effects for plants grown within both organic

Table 1. Soil volumetric water content (VWC) at a $15 \mathrm{~cm}$ depth for bell pepper grown under plastic mulch and strip tillage under different and irrigation regimes within organic and conventional production systems in Lexington, KY in 2011 and 2012.

\begin{tabular}{|c|c|c|c|c|c|}
\hline \multirow[b]{3}{*}{ Tillage method } & \multirow[b]{3}{*}{ Irrigation regime } & \multicolumn{4}{|c|}{$\operatorname{VWC}\left(\mathrm{cm}^{3} \cdot \mathrm{cm}^{-3}\right)$} \\
\hline & & \multicolumn{2}{|c|}{ Conventional } & \multicolumn{2}{|c|}{ Organic } \\
\hline & & 2011 & 2012 & 2011 & 2012 \\
\hline Plastic mulch & Well watered & $26.0 \mathrm{~A}^{\mathrm{z}}$ & $20.9 \mathrm{C}$ & $19.7 \mathrm{C}$ & $23.8 \mathrm{~A}$ \\
\hline Plastic mulch & Water restricted & $22.6 \mathrm{~B}$ & $20.5 \mathrm{C}$ & $18.8 \mathrm{C}$ & $22.5 \mathrm{~B}$ \\
\hline Strip tillage & Well watered & $25.3 \mathrm{~A}$ & $24.1 \mathrm{~A}$ & $25.6 \mathrm{~A}$ & $22.8 \mathrm{AB}$ \\
\hline Strip tillage & Water restricted & $23.1 \mathrm{~B}$ & $22.8 \mathrm{~B}$ & $22.3 \mathrm{~B}$ & $22.1 \mathrm{~B}$ \\
\hline
\end{tabular}

${ }^{\mathrm{z}}$ Means with the same in the same column letter are not significantly different according to Fisher's least significance test $(P \leq 0.05)$. and conventional systems. The yield_mid were 5 and $6 \mathrm{~d}$ later for strip-tillage-grown plants compared with plastic mulch-treated plants within the conventional system and $10 \mathrm{~d}$ later for strip-tillage-grown plants compared with plastic mulch-managed plants in the organic system in 2011 (Table 2).

In 2012, there was a significant tillage by irrigation regime interaction for number of marketable fruit for plants grown within the conventional system $(P \leq 0.05)$. Although trends were similar, the magnitude of change between irrigation regime and tillage system differed. The number of marketable fruit was significantly greater in the plastic mulch plots compared with the strip-tillage system. For conventionally grown plants in 2012, there was no impact of irrigation regime on marketable yield (weight). However, there was a significant effect of irrigation regime on the number marketable fruit produced within plastic mulch-grown plants in the conventional system in $2012(P \leq 0.05)$ (Table 2$)$. In 2012 , there was no difference in any system for marketable yield of organically grown plants; however, there were significant differences in number of marketable fruit per acre.

\section{Discussion}

Soil VWC reflected the irrigation treatments when measured at a $15 \mathrm{~cm}$ depth. When evaluating main effects, soil VWC was significantly greater for the well-watered than water-restricted treatments regardless of production system and study year except for the conventional system in 2012 (data not shown).

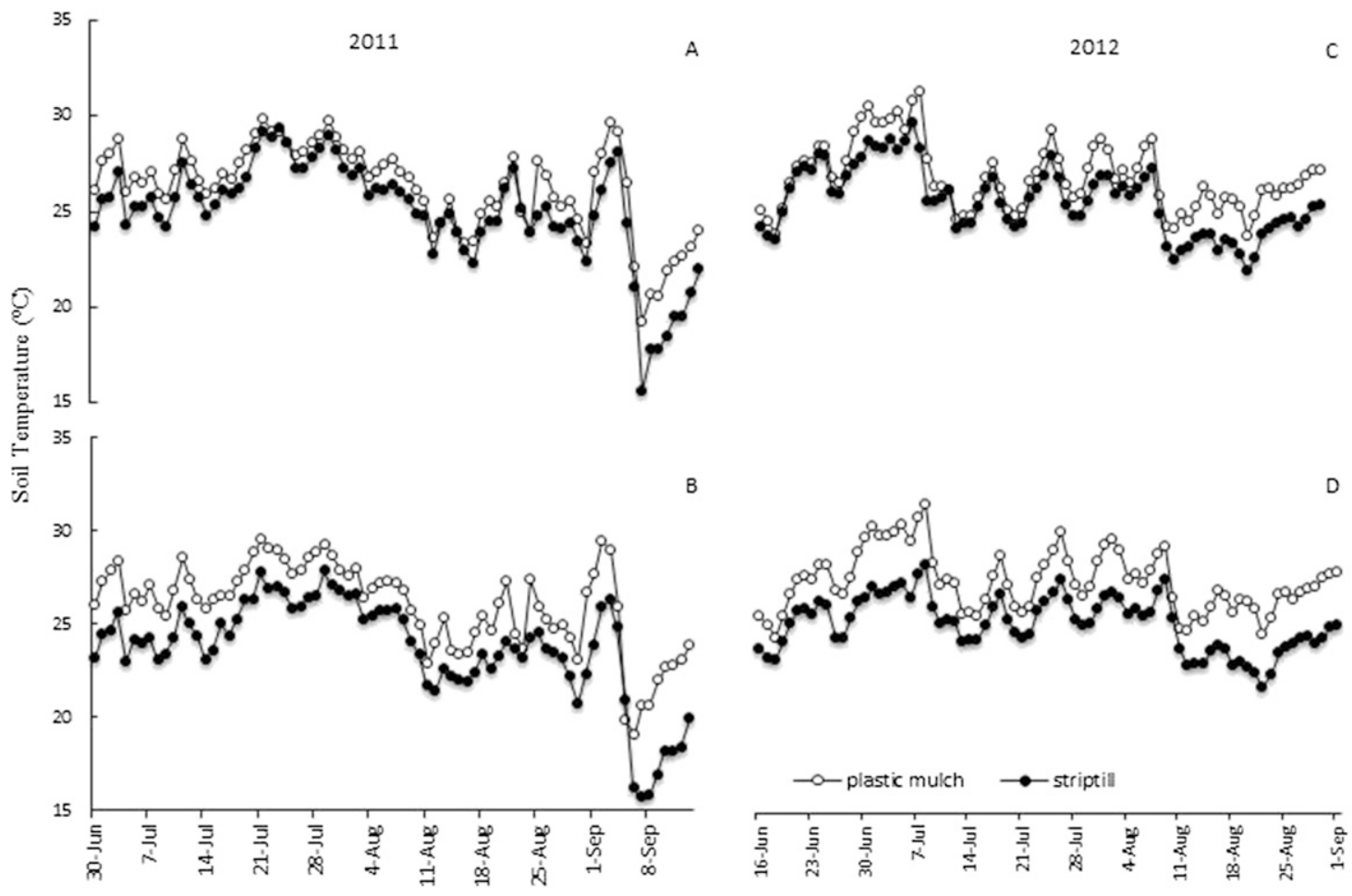

Fig. 1. Daily average soil temperature for plastic mulch strip-tillage treatments in the 2011 conventional (A) and organic (B) and 2012 conventional (C) and organic (D) trial seasons. 


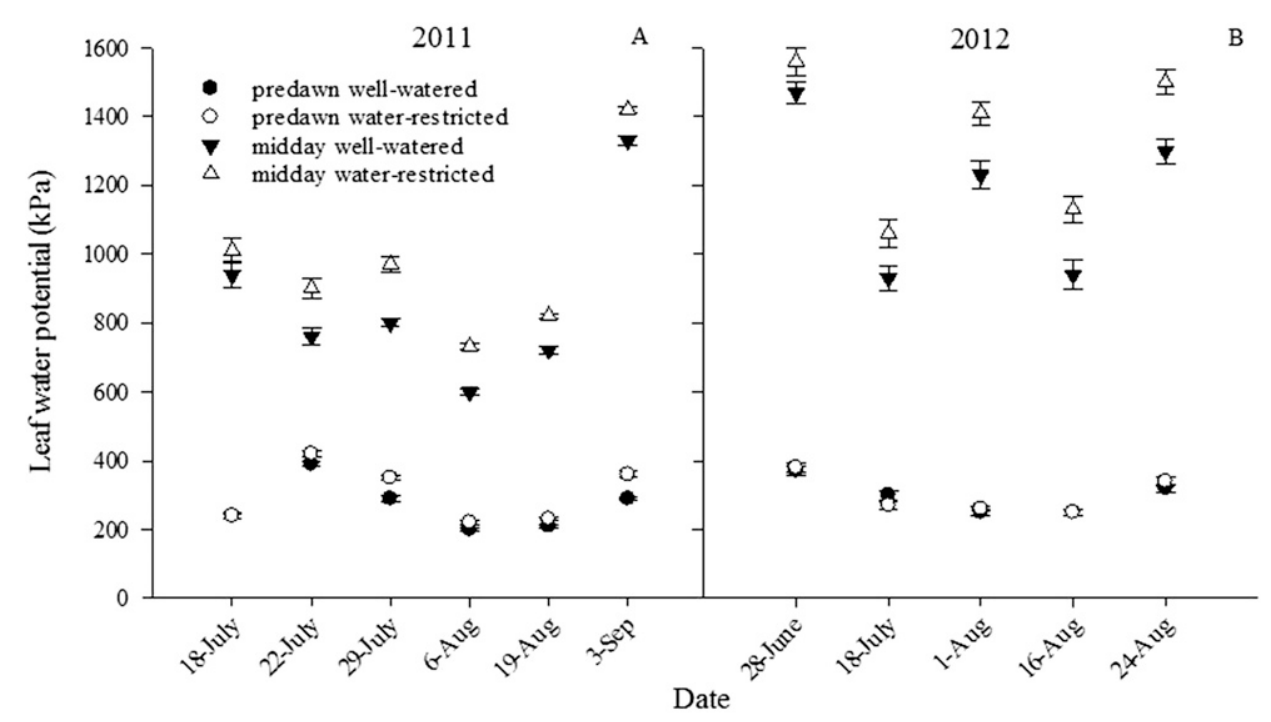

Fig. 2. Leaf water potential $\left(\Psi_{\mathrm{L}}\right)$ (absolute value, $\mathrm{kPa}$ ) for bell pepper grown under well-watered and water restricted irrigation regimes measured predawn and midday in 2011 (A) and 2012 (B). There were no interactions between treatments $(P \leq 0.05)$ for $\Psi_{\mathrm{L}}$.

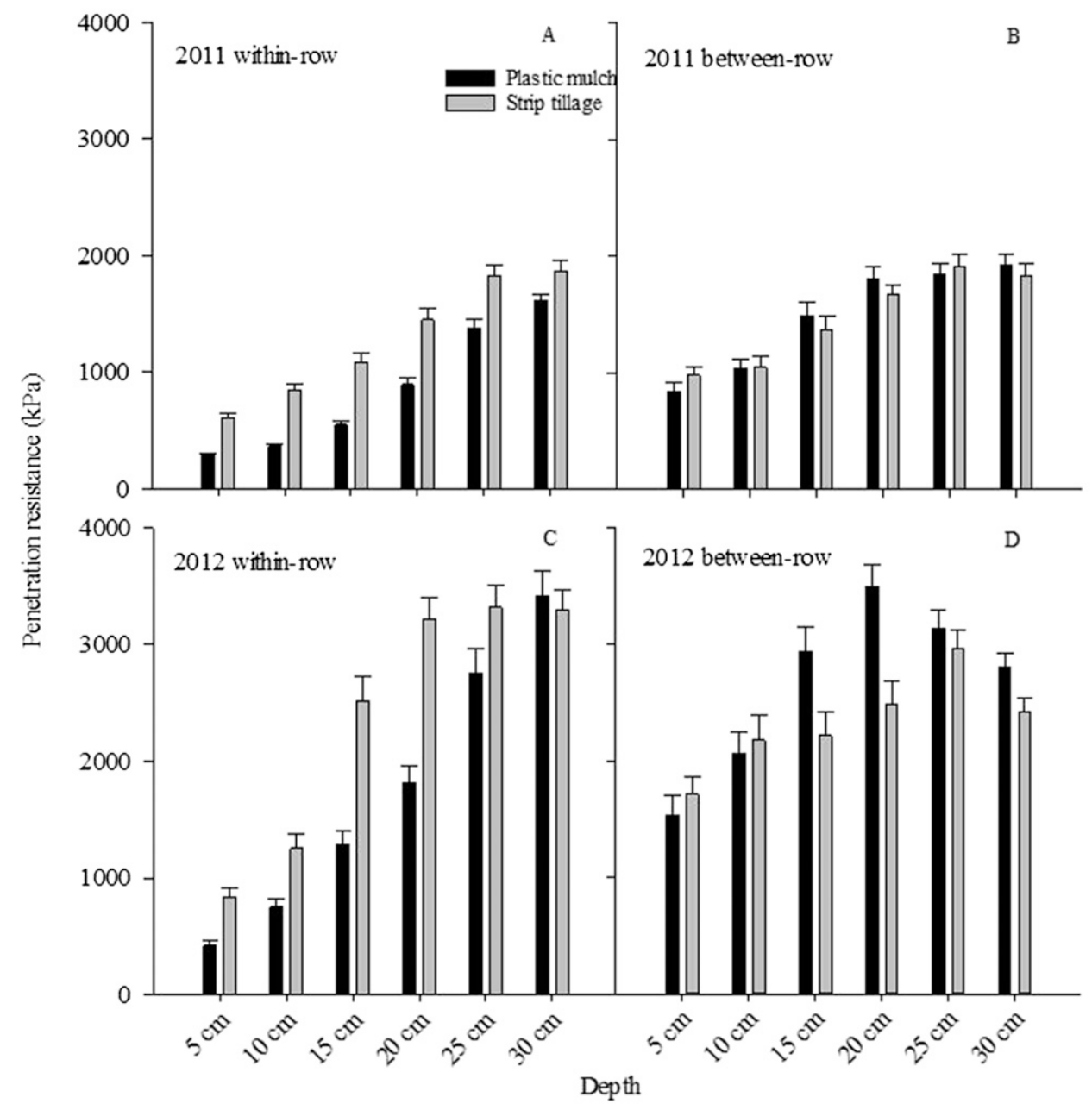

Fig. 3. Within- and between-row soil penetration resistance (kPa) measured at depths from 5 to $30 \mathrm{~cm}$ below soil surface for plastic mulch and strip-tillage plots in 2011 (A and B) and 2012 (C and D).

However, it should be noted that soil VWC in the well-watered treatments was still numerically greater than in the water-restricted treatments for both tillage systems in the conventional system in 2012. This suggests that the irrigation system used was successful in providing different levels of soil moisture to the plants in this trial. Midday $\Psi_{\mathrm{L}}$ data also suggest that the differences in irrigation regime were detectable in the plant.
There were interactions between tillage regime and irrigation treatments for soil VWC. Plots managed with strip tillage under well-watered conditions typically had a significantly greater soil VWC than under 
Table 2. Impact of tillage method and irrigation regime on marketable yield in weight and number of marketable and average fruit weight as well harvest midpoint (yield_mid) for bell pepper grown within organic and conventional production systems in Lexington, KY in 2011 and 2012.

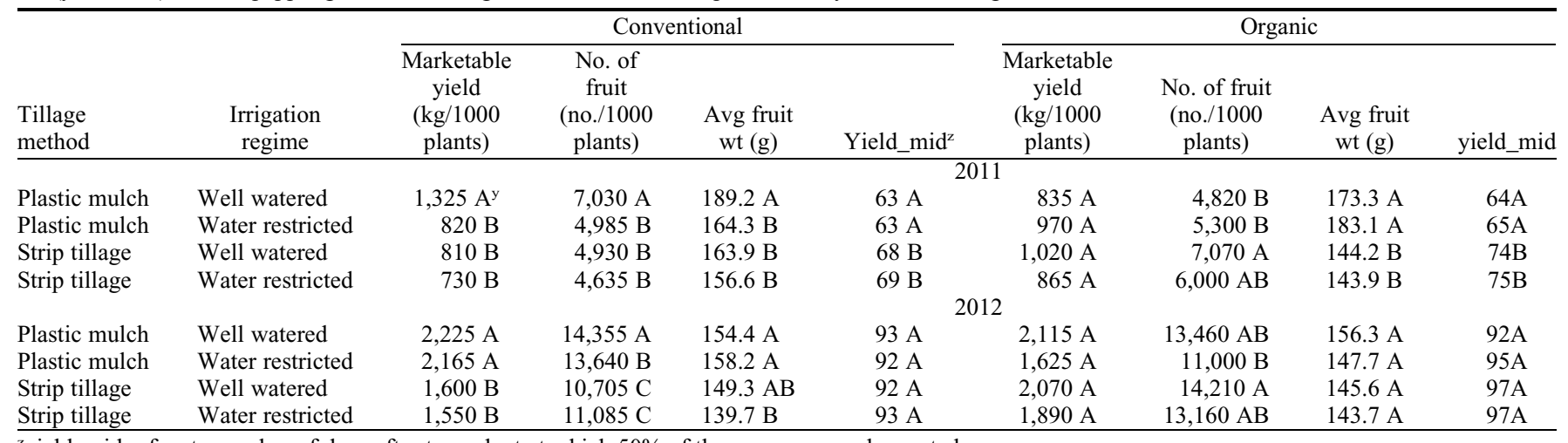

${ }^{z}$ yield_mid refers to number of days after transplant at which $50 \%$ of the peppers were harvested.

${ }^{y}$ Means with same letter within the same year and production system are not significantly different according to Fisher's least significance test $(P \leq 0.05)$.

water-restricted conditions. However, in the plastic mulch system, soil VWC, although numerically greater in the well-watered treatments, was not always significantly different when well-watered and water-restricted regimes were compared. Haramoto and Brainard (2012) reported a consistent increase in soil moisture levels in strip-tillage plots compared with conventional tillage; however, this was in bare-ground grown plants. It is typically accepted that plastic mulch can reduce evaporation, compared with bare-ground production (Lamont, 2005), which may change the dynamic of soil VWC in response to well-watered and water-restricted treatments compared with bare-ground systems.

Rain events may be another factor that contributed to the interaction of tillage and irrigation regime to affect soil VWC. After a rain event, soil VWC increased to a greater extent for strip-tillage plots than for plastic mulch plots. Precipitation amounts from 4 to 8 July in 2011 were $0.05,0.18,0.36,0.03$, and $2.03 \mathrm{~cm}$, respectively (Kentucky Mesonet, 2014). Correspondingly, soil VWC during this period ranged from 20.9 to $22.4 \mathrm{~cm}^{3} \cdot \mathrm{cm}^{-3}$ in the plastic mulch well-watered system, and 19.6 to $21.1 \mathrm{~cm}^{3} \cdot \mathrm{cm}^{-3}$ for the plastic mulchwater-restricted plots. In the strip-tillage plots, however, soil VWC ranged from 22.9 to $25.8 \mathrm{~cm}^{3} \cdot \mathrm{cm}^{-3}$ for well-watered plots and 21.7 to $24.2 \mathrm{~cm}^{3} \cdot \mathrm{cm}^{-3}$ for water-restricted plots. This may be expected as relatively minor rain events have little effect on soil VWC under plastic mulch (Nambuthiri and Coolong, unpublished data).

Soil temperatures generally were lower in strip-tillage plots compared with plastic mulch plots. One commonly noted negative aspect of strip tillage is that soil temperatures in bare-ground systems are generally lower compared with black plastic mulch (Lamont, 2005). However, Diaz-Perez and Batal (2002) reported that white-on-black plastic mulch, which was chosen to minimize the impact of soil temperature on this trial, generally will maintain root-zone temperatures similar to or even slightly below that of traditionally cultivated bare-ground production. The plastic mulch system in this trial used a raised bed, as is typical of this production system, whereas the strip-tillage system did not. A raised bed may have increased the surface area, which can intercept light and therefore enhance root-zone temperatures. In addition, the between-row areas of plastic mulch plots were tilled with no plant residue present, whereas the between-row areas of strip-tillage plots contained plant residue, particularly in the organically managed system, which used a roller crimper to maintain plant residue/ mulch between rows (cover crops in conventional plots were mowed). The residue between the rows of the strip-tillage plots may have effectively reduced root-zone temperatures. This may also explain the relatively greater difference in soil temperature between plastic mulch and strip-tillage plots within the organic system compared with the conventional systems for both years (Fig. 1). Mochizuki et al. (2007) reported an increase in soil temperatures of $1^{\circ} \mathrm{C}$ when the tillage zone was increased from 15 to $30 \mathrm{~cm}$, suggesting that increased plant residue between rows may decrease temperatures. In addition, the slightly higher soil temperature for 2012 compared with 2011 may be attributed to higher average air temperatures $\left(25.2{ }^{\circ} \mathrm{C}\right.$ vs. $\left.24.2{ }^{\circ} \mathrm{C}\right)$ and higher solar radiation during the trial period in 2012 than in 2011 (1705 vs. $\left.1511 \mathrm{MJ} \cdot \mathrm{m}^{-2}\right)$ (Kentucky Mesonet, 2014).

Predawn $\Psi_{\mathrm{L}}$ was unaffected by any treatment in either year; however, irrigation regime did affect midday $\Psi_{\mathrm{L}}$, with waterrestricted plants having a greater $\Psi_{\mathrm{L}}$ than well-watered plants. Differences in predawn $\Psi_{\mathrm{L}}$ can be difficult to detect when plants are grown under soil moisture levels that are reflective of those encountered during irrigated or mildly drought-stressed situations (Agele et al., 2006; Ceulemans et al., 1988; Donovan et al., 2001; Sato et al., 2006; Sellin, 1999). In this study, moderate differences in irrigation levels resulted in differences in midday $\Psi_{\mathrm{L}}$. Coolong et al. (2012) reported an effect of irrigation regime on midday $\Psi_{\mathrm{L}}$ but not predawn $\Psi_{\mathrm{L}}$ for poblano pepper grown with similar irrigation levels. This suggests that although tillage system may impact soil VWC, the effect on plant-water relations may be too small to be detected as changes $\Psi_{\mathrm{L}}$, particularly when compared with the impact of irrigation.

Penetration resistance is often used to evaluate tillage effects on soil compaction. A noted benefit of plastic mulch is reduced compaction within the planting area (Lamont, 2005). Although strip tillage involves using a subsoiler, a bed shaper used for applying raised-bed plastic mulch loosens a larger volume of soil than a single strip-tillage implement. Lower penetration resistance has been shown to primarily result from soil loosening by tillage (Mochizuki et al., 2007; Unger and Jones, 1998). In addition, between-row penetration resistance in plastic mulch and striptillage plots had distinct interactions compared with within-row penetration resistance. At depths of 15 and $20 \mathrm{~cm}$ in 2012, the between-row regions of strip-tillage plots had a lower penetration resistance than the between-row areas of plastic mulch plots (Fig. 3D). This may be the result of intact plant roots remaining from cover crops helping reduce compaction at these depths (Williams and Weil, 2004). This may have also been more likely to occur in the 2012 season as land used for strip tillage had not been tilled the prior year reflecting some changes that would occur over time in a conservation tillage system. In addition, the use of a rotary spader or moldboard plow for primary tillage in the plastic mulch plots could have caused a compacted layer at 15 and $20 \mathrm{~cm}$ depths, as this was the approximate depth of tillage provided with these implements in this study. Rotary spader implements, such as the one used for this study, function more similarly to a rotary tiller compared with an articulating spader, potentially resulting in soil skimming at the tillage depth. Moldboard plows also can leave a hard-pan layer at the depth of tillage.

Penetration resistance was in general greater in 2012 compared with 2011. Although penetration resistance was measured under similar soil moisture conditions, it should be noted that air temperatures were greater and rainfall lower in the period before the measurement in 2012 than in 2011 
(Kentucky Mesonet, 2014), which may have led to changes in soil physical properties, possibly affecting penetration resistance (Unger and Jones, 1998). As expected, within-row penetration resistance was significantly lower than between-row resistance within both production systems.

Marketable yields were the greatest for plastic mulch-treated plants grown in a wellwatered irrigation regime within conventional system in 2011 (Table 2). However in 2012, this treatment combination in the conventional system was not significantly different from plastic mulch-treated plants in water-restricted conditions. However, plastic mulch-grown plants still had significantly greater yields than strip-tillage-treated plants (Table 2). Black plastic mulch has been shown to increase yields of early-spring planted warm-season crops such as summer squash (C. pepo) compared with bare-ground production (Coolong, 2010). This is generally attributed to the soil-warming capabilities of black plastic mulch (Lamont, 1993). In the present study, white-on-black plastic mulch was used to minimize the impact of temperature. Root-zone temperatures under white plastic mulch have been reported to be $1-2{ }^{\circ} \mathrm{C}$ lower than black plastic mulch (Diaz-Perez, 2010). Despite using white-onblack plastic, soil temperatures in plastic mulch plots were still $1-2{ }^{\circ} \mathrm{C}$ greater than in strip-tillage plots.

The effects of tillage method on yield were different in the organic system compared with the conventionally grown system. In the organic system in 2011, plants grown in strip tillage under well-watered conditions had greater numbers of fruit than those plants grown with plastic mulch (Table 2). In 2012, there were no differences in yield between well watered organically managed plants grown in strip tillage or plastic mulch. These results are in contrast to Luna et al. (2012) who evaluated organically managed no-till or reduced-tillage production of tomato and eggplant (Solanum melongena L.) on farms in California's Central Valley. In an organic production system, yields of eggplant grown with conservation tillage were $80 \%$ less than the yield of eggplant using plastic mulch.

Although relative yields between plastic mulch and strip tillage were consistent within a given production system for both study years, the date at which $50 \%$ of marketable fruit (yield_mid) were harvested differed between plastic mulch and strip tillage within each production system in 2011. Plants grown under strip tillage had a yield_mid that was delayed compared with plastic mulch-grown plants in 2011. Although whiteon-black plastic mulch was used to minimize temperature differences between plots, it is likely that this difference in harvest date would be attributed to the lower soil temperatures in strip-tillage applications. For both organic and conventional strip-tillage systems in 2011 , there were $\approx 10 \mathrm{~d}$ with soil temperatures lower than $20{ }^{\circ} \mathrm{C}$ (Fig. 1). In 2012, there were $7 \mathrm{~d}$ with soil temperatures over $30{ }^{\circ} \mathrm{C}$ as well as no soil temperature lower than $20^{\circ} \mathrm{C}$ in any of the strip-tillage plots (Fig. 1). It is likely due to these higher temperatures that there were no significant differences between strip-tillage and plastic mulch plots the conventional and organic systems for yield_mid in 2012. It should be noted that the yield_mid was greater in 2012 compared with 2011 due to the longer harvest period that occurred in 2012 suggesting that yield_mid was most useful for treatments within a year. Jones and Popham (1997), Unger (1994), and Unger and Jones (1998) have reported that although final fruit yield may not be impacted by tillage method, plant development may be affected. Mochizuki et al. (2007) also reported that reasons for limited adoption of conservation tillage are reduced yields and delayed maturity resulting from cooler soils.

\section{Conclusions}

Within the conventional production system, plastic mulch with a well-watered irrigation regime was the highest yielding treatment in 2011. In 2012, marketable yield was greatest in plastic mulch-grown plants regardless of irrigation regime. The plastic mulch system was typically harvestable earlier and had greater marketable yields compared with the strip-tillage system for conventionally grown bell pepper. Our results also indicate that marketable yields of plants grown under strip tillage were not impacted by the irrigation regimes imposed in this trial. This suggests that in a conventional system, strip tillage may have limited yield potential to a greater degree than irrigation management and that the wellwatered irrigation treatment benefited plastic mulch-grown plants more than those in striptillage plots.

Although not directly compared, marketable yields in the organic system were similar to conventionally grown plants. However, unlike conventionally managed plants, yields among the four treatment combinations were similar for organically grown peppers. This suggests that other factors unique to the organic production system may be affecting yield in addition to tillage and irrigation regime. It should be noted that the mulch layer between rows in the strip-tillage plots within the organic system was insufficient to control weeds late in the growing season. This resulted in extensive hand cultivation. Had weeds not been managed this way, it is likely that plastic mulch-grown plants in the organic system would have had greater marketable yields than strip-tillage-grown plants due to competition from weeds in the strip-tillage plots. To be successful on a large scale, this obstacle would have to be overcome.

\section{Literature Cited}

Agele, S., S.S. Cohen, and S. Assouline. 2006. Hydraulic characteristics and water relations of net house-grown bell pepper as affected by irrigation regimes in a Mediterranean climate. Environ. Expt. Bot. 57:226-235.
Al-Kaisi, M. and M.A. Licht. 2004. Effect of strip tillage on corn nitrogen uptake and residual soil nitrate accumulation compared with no-tillage and chisel plow. Agron. J. 96:1164-1171.

Buyer, J.S., J.R. Teasdale, D.P. Roberts, I.A. Zasada, and J.E. Maul. 2010. Factors affecting soil microbial community structure in tomato cropping systems. Soil Biol. Biochem. 42:831-841.

Carrera, L.M., J.S. Buyer, B. Vinyard, A.A. AbdulBaki, L.J. Sikora, and J.R. Teasdale. 2007. Effects of cover crops, compost, and manure amendments on soil microbial community structure in tomato production systems. Appl. Soil Ecol. 37:247-255.

Ceulemans, R., I. Impens, M.C. Laker, F.M.G. Van Assche, and R. Mottram. 1988. Net $\mathrm{CO}_{2}$ exchange rate as a sensitive indicator of plant water status in corn (Zea Mays L.). Can. J. Plant Sci. 68:597-606.

Coolong, T. 2010. Performance of paper mulches using a mechanical plastic layer and water wheel transplanter for the production of summer squash. HortTechnology 20:319-324.

Coolong, T., R. Bessin, S. Wright, J. Strang, and K. Seebold. 2011a. Vegetable production guide for commercial growers 2012-13. Univ. Kentucky Coop. Ext. Serv. Bul. 36.

Coolong, T., S. Surendran, and R. Warner. $2011 \mathrm{~b}$. Evaluation irrigation threshold and duration for tomato grown in a silt loam soil. HortTechnology 21:466-473.

Coolong, T., J. Snyder, R. Warner, J. Strang, and S. Surendran. 2012. The relationship between soil water potential, environmental factors, and plant moisture status for poblano pepper grown using tensiometer-scheduled irrigation. Intl. J. Veg. Sci. 18:137-152.

Coolong, T., R. Warner, and J. Wilhoit. 2013. Methods for controlling soil moisture-based irrigation in field-grown vegetables. HortScience 48:S45 abstr.

Diaz-Perez, J.C. 2010. Bell pepper (Capsicum annuum L.) grown on plastic film mulches: Effects on crop microenvironment, physiological attributes, and fruit yield. HortScience 45:1196-1204.

Diaz-Perez, J.C. and K.D. Batal. 2002. Colored plastic film mulches affect tomato growth and yield via changes in root-zone temperature. $\mathrm{J}$. Amer. Soc. Hort. Sci. 127:127-136.

Donovan, L.A., M.J. Linton, and J.H. Richards. 2001. Predawn plant water potential does not necessarily equilibrate with soil water potential under well-watered conditions. Oecologia 129:328-335.

Haramoto, E.R. and D.C. Brainard. 2012. Strip tillage and oat cover crops increase soil moisture and influence $\mathrm{N}$ mineralization patterns in cabbage. HortScience 47:1596-1602.

Hemphill, D.D. 1993. Agricultural plastics as solid waste: What are the options for disposal? HortTechnology 3:70-73.

Hoyt, G.D. 1992. Effect of cover crop and $\mathrm{N}$ rate on soil $\mathrm{N}$ and yield of no-till sweet corn and striptill tomato. HortScience 27:663 abstr.

Jones, O.R. and T.W. Popham. 1997. Cropping and tillage systems for grain production in the southern High Plains. Agron. J. 89:222-232.

Jury, W.A. and R. Horton. 2004. Water flow under natural conditions, p. 118-160. In: W.A. Jury and R. Horton (eds.). Soil physics. Wiley, Hoboken, NJ.

Kentucky Mesonet. 2014. Lexington, Fayette County climate data. 10 Sept. 2014. $<$ http:// www.kymesonet.org/historical_data.php>.

Kong, A.Y.Y., S.J. Fonte, C.V. Kessel, and J. Six. 2009. Transitioning from standard to minimum tillage: Trade-offs between soil organic matter stabilization, nitrous oxide emission, and $\mathrm{N}$ 
availability in irrigated cropping systems. Soil Tillage Res. 104:256-262.

Lamont, W.J. 1993. Plastic mulches for the production of vegetable crops. HortTechnology 3: 35-39.

Lamont, W.J. 2005. Plastics: Modifying the microclimate for the production of vegetable crops. HortTechnology 15:477-481.

Licht, M.A. and M. Al-Kaisi. 2005. Corn response, nitrogen uptake, and water use in strip-tillage compared with no-till and chisel plow. Agron. J. 97:705-710.

Locascio, S.J. 2005. Management of irrigation for vegetables: Past, present, and future. HortTechnology 15:482-485.

Luna, J.M. 2003. Conservation tillage systems for organic vegetable production. Organic Farming Res. Foundation Info. Bul. 12:14-16.

Luna, J.M. and M.L. Staben. 2002. Strip tillage for sweet corn production: Yield and economic return. HortScience 37:1040-1044.

Luna, J.M., J.P. Mitchell, and A. Shrestha. 2012. Conservation tillage for organic agriculture: Evolution toward hybrid systems in the western USA. Renew. Agr. Food Syst. 27:21-30.

Mochizuki, M.J., A. Rangarajan, R.R. Bellinder, T. N. Bjorkman, and H.M. van Es. 2007. Overcoming compaction limitations on cabbage growth and yield in the transition to conservation tillage. HortScience 42:1690-1694.

Mochizuki, M.J., A. Rangarajan, R.R. Bellinder, H.M. van Es, and T.N. Bjorkman. 2008. Rye mulch management affects short-term indicators of soil quality in the transition to conservation tillage for cabbage. HortScience 43:862-867.

Morrison, J.E. 2002. Strip tillage for "no-till" row crop production. Appl. Eng. Agr. 18:277-284.

Oregon State University. 2011. Organic fertilizer and cover crop calculator. 5 May 2011. <http:// smallfarms.oregonstate.edu/calculator>.

Rapp, H.S., R.R. Bellinder, H.C. Wien, and F.M. Vermeylen. 2004. Reduced tillage, rye residues, and herbicides influence weed suppression and yield of pumpkins. Weed Technol 18:953-961

Roper, M.M., V.V.S.R. Gupta, and D.V. Murphy. 2010. Tillage practices altered labile soil organic carbon and microbial function without affecting crop yields. Austral. J. Soil Res. 48:274-285.

Sato, T., O.S. Abdalla, T.Y. Oweis, and T. Sakuratani. 2006. The validity of predawn leaf water potential as an irrigation-timing indicator for field-grown wheat in northern Syria. Agr. Water Mgt. 82:223236.

Scholander, P.F., E.D. Bradstreet, E.A. Hemmingsen, and H.T. Hammel. 1965. Sap pressure in vascular plants negative hydrostatic pressure can be measured in plants. Science 148:339-346.

Sellin, A. 1999. Does pre-dawn water potential reflect conditions of equilibrium in plant and soil water status? Acta Oecol. 20:51-59.

Unger, P.W. and O.R. Jones. 1998. Long-term tillage and cropping systems affect bulk density and penetration resistance of soil cropped to dryland wheat and grain sorghum. Soil Tillage Res. 45:39-57.

Unger, P.W. 1994. Tillage effects on dryland wheat and sorghum production in the southern Great Plains. Agron. J. 86:310-314.

U.S. Department of Agriculture. 2005. United States standards for grades sweet pepper. U.S. Dept. Agr., Washington, DC.

U.S. Department of Agriculture. 2014. United States code of federal regulations, National Organic Progam. Title 7-B 1 m 205. U.S. Dept. Agr., Washington, DC.

Wagner-Riddle, C., T.J. Gillespie, L.A. Hunt, and C.J. Swanton. 1997. Modeling a rye cover crop and subsequent soybean yield. Agron. J. 89:208-218.

Walters, S.A. 2011. Weed management systems for no-till vegetable production, p. 17-40. In: S. Soloneski and M.L. Larramendy (eds.). Herbicides, theory, and applications. InTech, Rijeka, Croatia.

Wilhoit, J.H., R.D. Morse, and D.H. Vaughan. 1990. Strip-tillage production of summer cabbage using high residue levels. Appl. Agr. Res. 5:338-342.

Williams, S.M. and R.R. Weil. 2004. Crop cover root channels may alleviate soil compaction effects on soybean crop. Soil Sci. Soc. Amer. J. 68:1403-1409. 